\title{
SPRAWA ZABÓJSTWA JÓZEFA CECHNOWSKIEGO W 1925 ROKU A ROLA STANISŁAWA RADKIEWICZA
}

\author{
Monika Piotrowska \\ Uniwersytet Jagielloński w Krakowie
}

\begin{abstract}
THE CASE OF THE MURDER OF JÓZEF CECHNOWSKI IN 1925 AND THE ROLE OF STANISŁAW RADKIEWICZ
\end{abstract}

The purpose of this article is to fill the gaps in the biography of Stanisław Radkiewicz by describing the period of his communist activity in Lviv. It focuses on Radkiewicz as one of the organizers of the assassination of Józef Cechnowski. Cechnowski, a police informer (a so-called agent provocateur), was killed by Naftali Botwin in July 1925. Therefore, this paper may be a contribution to Botwin's biography as well. The article presents this event in a broader historical context, which is essential to explain the socio-political background and the consequences of the assassination. It also shows some aspects of the Botwin myth created by the Communist Party of Poland and supported by the authorities of the Polish People's Republic. The sources used as the basis of the article are archival documents, especially personal files and memories of direct participants and witnesses of these events in Lviv. It is a little-known episode which had a significant impact not only on Radkiewicz's career but also on the labour movement in Poland.

Key words: Stanisław Radkiewicz, Naftali Botwin, Communist Party of Poland, agent provocateur, assassination, Lviv, Polish People's Republic, Józef Cechnowski, interwar period, terror.

Słowa kluczowe: Stanisław Radkiewicz, Naftali Botwin, KPP, prowokator, zamach, Lwów, Polska Rzeczpospolita Ludowa, Józef Cechnowski, dwudziestolecie międzywojenne, terror. 


\section{WSTĘP}

Ruch komunistyczny był skierowany przeciwko polskiemu porządkowi prawnemu, a także międzynarodowym ustaleniom granicznym, zmierzając do obalenia władzy w Polsce oraz włączenia zachodniej Ukrainy do strefy wpływów ZSRR². Współpraca między polskimi i ukraińskimi komunistami charakteryzowała się wieloma animozjami o charakterze narodowym. Wynikały one głównie z prób uzyskania przez mieszkańców Małopolski Wschodniej szerokiej partyjnej autonomii, a zatem możliwości samodzielnych i niezależnych działań2. Większość lokalnych komunistów niechętnie podporządkowywała się strukturom Komunistycznej Partii Polski ${ }^{3}$ i rozkazom jej kierownictwa ${ }^{4}$. Z drugiej zaś strony struktury KPP stawały się szkołą partyjnej pracy dla działaczy Komunistycznej Partii Zachodniej Ukrainy (KPZU) Odrębną kwestię stanowi także liczny udział ludności żydowskiej w rozwijającym się ruchu robotniczym.

Sprawozdanie sytuacyjne Komendy Policji Państwowej we Lwowie za lipiec 1922 roku pokazuje, na czym polegały wzajemne relacje, a mianowicie:

1 W okresie międzywojennym pojawiały się różne pomysły i koncepcje polityczne preferowane przez Komintern, KPP lub KPZU: oderwania tych ziem od Polski w celu bezpośredniego włączenia ich do ZSRR, utworzenia Radzieckiej Ukrainy Zachodniej, powstania odrębnego socjalistycznego państwa zachodnioukraińskiego w strefie wpływów ZSRR, włączenia zachodniej Ukrainy do już istniejącej Ukraińskiej Republiki Radzieckiej (tzw. Ukraina Wschodnia), a także pozostawienia ich na zasadzie autonomii terytorialnej w granicach powstałej w wyniku walk rewolucyjnych Polskiej Republiki Radzieckiej, funkcjonującej w ramach ZSRR. Różnice w dążeniach politycznych w ruchu komunistycznym stały się przyczyną wzajemnych konfliktów oraz oskarżeń o zdradę i nacjonalizm; Por. M. Pyrig, Взаємини Комуністичної Партії Західної України та Комуністичної Партії Польщі у 1920-х pp., „Кomunizm: system-ludzie-dokumentacja” 2014, s. 21-48; Zob. M. Pyrig, УКРАЇНСЬКИЙ ЛІВОРАДИКАЛЬНИЙ РУХ У ПОЛЬЩІ (1919-1929 pp.), praca doktorska, Uniwersytet Lwowski, [b.m.w.] 2016, s. 102-118.

2 Część działaczy KPZU opowiadała się za powstaniem zbrojnym i przyłączeniem tych ziem do USRR. Natomiast Komintern głosił hasło rewolucji na wszystkich ziemiach należących do Polski. Ogromnie ważną rolę odgrywały nastroje nacjonalistyczne. W latach 1924-1925 pojawił się w KPZU nurt dywersyjno-sabotażowy i tendencje separatystyczne względem KPP, a niektórzy działacze bardziej liczyli na zbrojną pomoc Armii Czerwonej niż na efekty walki rewolucyjnej.

316 grudnia 1918 r. w wyniku zjednoczenia dwóch partii rewolucyjnych - Socjaldemokracji Królestwa Polskiego i Litwy oraz Polskiej Partii Socjalistycznej-Lewicy - powstała Komunistyczna Partia Robotnicza Polski (KPRP, a od 1 lutego 1925 r. Komunistyczna Partia Polski).

4 Zasadniczy był problem bronionego przez Ukraińców „prawa narodów do samostanowienia” i oderwania rewolucji ukraińskiej od ogólnoświatowej.

5 II Zjazd KPRP (19 września - 2 października 1923 r.) podjął decyzję o utworzeniu KPZU jako autonomicznej organizacji obwodowej KPRP. Natomiast Komunistyczny Związek Młodzieży Zachodniej Ukrainy (KZMZU) powstał z przekształcenia działającego od 1921 r. ZMK Partii Galicji Wschodniej. Miał on funkcjonować na terenach położonych na wschód od Bugu, zamieszkałych w większości przez ludność ukraińską. Stanowił autonomiczną organizację obwodową w ramach ZMK w Polsce z własnym Komitetem Centralnym. 
[...] istniejący na tutejszym terenie Związek Młodzieży Komunistycznej ${ }^{6}$, którego członkowie rekrutują się wyłącznie prawie z ludności żydowskiej, pozostaje w stałym kontakcie z Warszawą, skąd też otrzymuje bibułę oraz wychodzące tamże czasopismo „Towarzysz” będące organem komunistycznej młodzieży. Pisma te rozsyłane zostają następnie przez tzw. „techników” ze Lwowa na prowincję?.

W marcu 1923 roku oceniono, że na terenie województwa lwowskiego to Żydzi stanowili ok. 95\% członków ZMK ${ }^{8}$, a także większość wśród członków KPZU. To oni uczynili ze Lwowa centrum ruchu komunistycznego na terenie zachodniej Ukrainy.

Organizacje komunistyczne na ziemiach polskich działały nielegalnie, dlatego borykały się z problemem ciągłej inwigilacji ze strony policji politycznej, a w konsekwencji z masowymi aresztowaniami. Defensywa ${ }^{9}$ odnosiła znaczące sukcesy dzięki metodzie przenikania konfidentów - tzw. ,prowokatorów” - do ruchu robotniczego. Policja starała się zdezintegrować struktury każdego szczebla Komunistycznej Partii Polski i Związku Młodzieży Komunistycznej, a co za tym idzie również podległe im KPZU i Komunistyczny Związek Młodzieży Zachodniej Ukrainy (KZMZU). Prowokatorzy mieli za zadanie m.in. donosić na swych towarzyszy czy podrzucać kompromitującą bibułę ${ }^{10}$. Komuniści postanowili przeciwdziałać poprzez akcję rewolucyjnej samoobrony. Polegała ona przede wszystkim na likwidacji konfidentów. Dokonywać się to miało na mocy wyroków wydanych przez sądy partyjne. Ten temat był podejmowany na zorganizowanym w Moskwie III Zjeździe Partii (14 stycznia - 4 lutego 1925 r.), po którym w działalności KPP i ZMK zaczęły się przejawiać coraz silniejsze tendencje terrorystyczne ${ }^{11}$.

Przedmiotem niniejszego artykułu jest właśnie jeden z aktów ,partyjnej samoobrony”, czyli udany zamach na prowokatora Józefa Cechnowskiego, którego współorganizatorem był Stanisław Radkiewicz, a jego wykonawcą Naftali Botwin. W tym miejscu należy przybliżyć sylwetki tych osób, grających pierwszoplanową rolę w omawianej sprawie.

Izaak Naftali Botwin (1905-1925) od 1922 roku był członkiem organizacji Cukunft $^{12}$. Pracował jako przykrawacz szewski. Skończył trzy klasy szkoły powszechnej. W 1923 roku przyłączył się do Związku Młodzieży Komunistycznej w Polsce.

${ }^{6}$ Oficjalnie Związek Młodzieży Komunistycznej w Polsce powstał na mocy decyzji swego I Zjazdu 17 marca 1922 r. w Warszawie. Za: L. Krzemień, Związek Młodzieży Komunistycznej w Polsce. Pierwsze dziesięciolecie (1918-1928), Warszawa 1972, s. 63.

7 Państwowe Archiwum Obwodu Lwowskiego (Derżawnyj Archiw Lwiwśkoji Obłasti, dalej: DALO), fond 121, opis 1, sprawa 53, k. 127 [za:] G. Mazur, Życie polityczne polskiego Lwowa 1918 1939, Kraków 2007, s. 378-379.

8 Ibidem.

9 Defensywa - tego terminu używano w Polsce w okresie międzywojennym na określenie Oddziału II Sztabu Generalnego Wojska Polskiego, zajmującego się wywiadem i kontrwywiadem.

10 Zob. K. Halicki, Policja polityczna w Polsce w okresie międzywojennym [w:] Wywiad i kontrwywiad wojskowy II RP, t. 1, red. T. Dubicki, Łomianki 2010, s. 295-313; A. Pepłoński, Policja Państwowa w systemie organów bezpieczeństwa Drugiej Rzeczypospolitej, Szczytno 1991.

11 Zob. A. Czubiński, Komunistyczna Partia Polski (1918-1938). Zarys historii, Warszawa 1985, s. $123-130$.

12 Związek Młodzieży „Cukunft” (Przyszłość) - lewicowa żydowska organizacja młodzieżowa Bundu. Został założony w 1910, a w 1916 r. otrzymał oficjalnie nazwę Jugnt Bund „Cukunft”. 
Od 1924 roku był członkiem Wydziału Zawodowego ZMK we Lwowie, a od roku 1925 KPZU. W 1925 roku żydowskie i polskie Związki Zawodowe Szewców zostały połączone, a Botwina wybrano do nowego zarządu ${ }^{13}$. Przyjmował pseudonimy „Filip”, „Ćwinek” i „Tulu”. Rok 1925 okazał się dla niego przełomowym, być może dlatego, iż poznał Stanisława Radkiewicza (1903-1987), który wtajemniczył go w planowany zamach.

Radkiewicz, po odbyciu dwuletnich studiów (1922-1924) na Uniwersytecie Mniejszości Narodowych Zachodu im. Juliana Marchlewskiego (na wydziale pracy partyjnej i edukacji politycznej) ${ }^{14}$, prosto z Moskwy udał się na ziemie ukraińskie (na Podole). Pracował tam od maja 1924 do 15 kwietnia 1925 roku, pełniąc funkcję sekretarza polskiego biura przy Komitecie Wojewódzkim Komunistycznego Związku Młodzieży Ukraińskiej (LKSMU) w Kamieńcu Podolskim i Winnicy ${ }^{15}$. Jego kariera partyjna nabierała tempa, gdyż już miesiąc później 22-latek został nielegalnie wysłany na ziemie Rzeczpospolitej, aby stać się członkiem Sekretariatu Komitetu Centralnego Komunistycznego Związku Młodzieży Zachodniej Ukrainy we Lwowie. Jeszcze w tym samym roku brał udział w II Zjeździe Komunistycznej Partii Zachodniej Ukrainy (październik 1925 r.) ${ }^{16}$. Powyższe stanowisko piastował do stycznia 1926 roku, ponieważ wtedy awansował do roli instruktora do spraw chłopskich w Komitecie Centralnym Komunistycznego Związku Młodzieży Polski (KZMP) we Lwowie ${ }^{17}$. W międzyczasie (1925) został także członkiem Komunistycznej Partii Polski. W tym okresie posługiwał się nazwiskiem „Lenczewski” (panieńskie nazwisko matki) oraz pseudonimem „Pietka”. To właśnie ten mało znany epizod lwowski miał w znaczący sposób zaważyć nie tylko na karierze przyszłego szefa bezpieki, ale także na całym ruchu robotniczym.

Dzisiaj dysponujemy niemal wyłącznie doniesieniami prasy z tamtego okresu oraz wspomnieniami uczestników wypadków lwowskich, zapisywanymi lub też nagrywanymi z dystansu czasowego, w latach 50. i 60. XX wieku. Opracowania historyczne nie zajmowały się zbadaniem tego zagadnienia. Temat Cechnowskiego czy Botwina najczęściej pojawia się w historiografii w kontekście walki politycznej między KPP a organami władzy państwowej II RP. Zostaje opisany lakonicznie i fragmentarycznie, zazwyczaj z perspektywy ideologicznej. Z powyższych powodów warto zestawić różne wersje tych samych wydarzeń, aby ustalić tę jedną, najbardziej prawdopodobną. W tym miejscu należy zaakcentować fakt, iż wspomnienia o Botwinie były zbierane przez Zakład Historii PZPR od początku lat 50., a sam Radkiewicz ujawnił swe zaangażowanie w tę sprawę dopiero w 1963 roku; wcześniej ani on, ani

13 Zob. Botwin Naftali [w:] Stownik biograficzny dziataczy polskiego ruchu robotniczego, red. F. Tych, t. I, Warszawa 1978, s. 231-232.

14 Rosyjskie Państwowe Archiwum Historii Społeczno-Politycznej (Rossijskij Gosudarstwiennyj Archiw Socyalno-Politiczeskoj Istorii, dalej: RGASPI), fond 495, Komintern, opis 252, dieło 119, Akta personalne Stanisława Radkiewicza, k. 7.

15 Ibidem, k. 25.

16 Archiwum Akt Nowych (dalej: AAN), KPZU, sygn. 165/I-2/t. 9, II Zjazd KPZU, k. 12-13.

17 Zob. J. Radziejows ki, Ideologiczne i organizacyjne ksztaltowanie się ruchu komunistycznego na terenie Ukrainy Zachodniej w latach 1918-1923, „Z Pola Walki” 1971, nr 2, s. 27; idem, KPZU 1919-1929. Węzłowe problemy ideologiczne, Kraków 1976. 
nikt inny nigdy o tym nie wspomniał. Dlaczego? Zapewne jego uczestnictwo w zamachu było niewygodne i tuszowane z powodów propagandowych oraz politycznych, gdyż partia w ostateczności potępiła terrorystyczną działalność poprzedników.

\section{DWA ZAMACHY NA JÓZEFA CECHNOWSKIEGO}

Sprawa Józefa Cechnowskiego ${ }^{18} \mathrm{z}$ Warszawy zyskała wielki rozgłos. Jako delegat robotników fabryki Budowa Parowozów w Warszawie kierował on w połowie 1921 roku strajkiem metalowców. Jednakże wkrótce potem został wywiadowcą Okręgowego Urzędu Policji Politycznej w Warszawie. Po przedostaniu się do Komitetu KPP jako funkcjonariusz defensywy przeprowadzał aresztowania oraz rewizje w mieszkaniach członków KPP i ZMK. Stanisław Radkiewicz przyznał, iż:

Cechnowski na początku lat dwudziestych był aktywistą partyjnym w Warszawie i wchodził nawet do KW KPP w Warszawie. Okazało się potem, że jest to bardzo szkodliwy prowokator. Grasował on po dzielnicach robotniczych Warszawy i oddał w ręce policji niemało aktywu partyjnego, a następnie stawał na procesach jako świadek oskarżenia. Decyzją KC KPP skazany został na unieszkodliwienie i śmierć ${ }^{19}$.

Był on zamieszany m.in. w największy bombowy zamach terrorystyczny okresu międzywojennego, a mianowicie wysadzenie prochowni Cytadeli warszawskiej 13 października 1923 roku. Zginęło wtedy 28 osób, zaś 90 zostało poważnie rannych. Do dzisiaj historycy nie są pewni, którzy działacze KPP zorganizowali i wykonali ów zamach. Pewne jest tylko jedno: Józef Cechnowski był głównym świadkiem w procesie przeciwko oskarżonym o przygotowanie zamachu: porucznikowi Waleremu Bagińskiemu i podporucznikowi Antoniemu Wieczorkiewiczowi ${ }^{20}$, którzy już odsiadywali wyrok za ataki bombowe z kwietnia i maja 1923 roku oraz przynależność do KPP ${ }^{21}$. Prokuratura nie dysponowała żadnymi dowodami. Jednakże Józef Piątkiewicz, inspektor, który zwerbował Cechnowskiego do współpracy z policją, wykorzystał go jako świadka koronnego ${ }^{22}$. Prezydent Stanisław Wojciechowski udzielił Bagińskiemu i Wieczorkiewiczowi ułaskawienia, zmieniając ich karę śmierci na dożywocie ${ }^{23}$.

18 AIPN, MBP, sygn. 1572/1615, Konfidenci i prowokatorzy Policji Państwowej do 1939 r. Członkowie KPP i KZMP w województwie warszawskim.

19 AAN, Zbiór akt osobowych działaczy ruchu robotniczego 1918-1990, sygn. 689, Botwin Naftali, O Naftalim Botwinie, Relacja Stanisława Radkiewicza nagrana w ZHP dnia 5 listopada 1963 r., k. 36.

20 Zob. Bagiński Walery [w:] Stownik biograficzny..., s. 86; Ł. Łabędzki, Na granicy dwóch światów. Walery Bagiński 1893-1925. Biografia, Łódź 2010.

${ }_{21}$ Zob. I. Orzechowski, Z okazji 23-rocznicy bohaterskiej śmierci tow. Botwina, „Trybuna Robotnicza" 1948 , z. 1350, s. 5.

22 Wśród akt spraw prowadzonych przez Wojskowy Sąd Okręgowy w Warszawie, znajdujących się w Archiwum Akt Nowych, nie zachowały się akta procesu przeciwko Bagińskiemu i Wieczorkiewiczowi; zob. AAN, Akta sądów wojskowych, sygn. 427/II/1-88.

23 A. Pragier, Czas przeszly dokonany, Londyn 1966, s. 286. 
Zagadka zamachu terrorystycznego pozostaje nierozwiązana, nie wyjaśniono również okoliczności zabójstwa obu oskarżonych. Miało ono miejsce w drodze na wymianę więźniów politycznych na granicy wschodniej, ustaloną z rządem ZSRR ${ }^{24}$. Ich zabójca, Józef Muraszko, szef ekspozytury śledczej w Stołpcach, wyszedł z więzienia (za podwójne morderstwo) po dwóch latach ${ }^{25}$.

17 lipca 1925 roku wyrok KPP na Cechnowskim mieli wykonać jej członkowie: Władysław Hibner, Władysław Kniewski ${ }^{26}$ i Henryk Rutkowski ${ }^{27}$. Zostali jednak zdekonspirowani, a na warszawskiej ulicy wywiązała się strzelanina, w której zginęli policjant i osoba cywilna, zaś zamachowców złapano. Jednakże partia nie przestała ścigać Cechnowskiego, a jego los miał dopełnić się właśnie we Lwowie, w czym niepośledni swój udział miał Stanisław Radkiewicz. Dlatego to jego relacja stanowi jedno z najważniejszych źródeł przy omawianiu wydarzeń lwowskich.

Było to latem $1925 \mathrm{r}$. Mirek Zdziarski ${ }^{28}$ wchodził wtedy w skład Sekretariatu KC KPZU, jako przedstawiciel KPP i był we Lwowie. Ja kontaktowałem się z nim z ramienia młodzieży, on pracował po linii partyjnej. Kiedy prowokator Cechnowski przyjechał na proces jako świadek - ja miałem wtedy akurat spotkanie ze Zdziarskim, który powiedział, że zna Cechnowskiego osobiście i że dobrze by było wykonać dawną decyzję partii. Zapytał, czy mamy kogoś, kto mógłby wykonać wyrok. Odpowiedziałem mu, że nie jest łatwo zadecydować o tym na poczekaniu, ale mam jedną kandydaturę i powiedziałem mu o Botwinie. Mieszkałem wtedy jako nie-

24 Zob. Wymiana więźniów politycznych między II Rzeczpospolita a Sowietami w okresie międzywojennym. Dokumenty i materiaty, oprac. W. Materski, Warszawa 2000, s. 152.

25 Por. F. Hoesick, Sprawa Józefa Muraszki: zabójstwo Bagińskiego i Wieczorkiewicza, Warszawa 1926; Po odbyciu kary zmienił nazwisko na Leonardi i zaciągnął się do Korpusu Ochrony Pogranicza. Jednakże pod koniec 1939 r. występował jako oficer gestapo i Polskie Państwo Podziemne wykonało na nim wyrok śmierci.

26 Zob. R. Toruńczyk, O Mietku Kniewskim, który poszedt w ślady swego brata [w:] Kazetemowcy. Zbiór szkiców i biograficznych wspomnień, red. R. Toruńczyk i W. Góra, Warszawa 1963, s. 152-156.

27 Władysław Hibner był uczestnikiem rewolucji 1905 r. Należał do egzekutywy Komitetu Warszawskiego KPP, zaś Władysław Kniewski i Henryk Rutkowski w 1922 r. wstąpili do ZMK. Kniewski został członkiem aktywu Komitetu Warszawskiego ZMK, a Rutkowski Komitetu Dzielnicowego Wola.

28 Mirosław Zdziarski (1892-1937) - działacz ruchu robotniczego, publicysta, z zawodu buchalter. Od 1908 r. działał w Polskiej Partii Socjalistycznej (PPS) Lewica, w latach 1912-1915 przebywał w więzieniu i na zesłaniu, był uczestnikiem rewolucji październikowej 1917 r. w Moskwie. Od 1918 r. przebywał w kraju. Był współzałożycielem Komunistycznej Partii Polski, członkiem Komisji Centralnej Związków Zawodowych. W latach 1924-1925 był członkiem kierownictwa Komunistycznej Partii Zachodniej Ukrainy. Po zamachu na Cechnowskiego, w sierpniu 1925 r., z uwagi na grożącą mu dekonspirację wyjechał z Lwowa. Uwięziono go jednak w Warszawie (1926). Po ucieczce do ZSRR (1926) został pracownikiem Czerwonej Międzynarodówki Związków Zawodowych. Aresztowany (1937) i skazany na śmierć, w 1956 r. zrehabilitowany przez władze komunistyczne. Przyjmował następujące nazwiska i pseudonimy, m.in.: „Lipiński”, „Stanisław Gozdawa”, „Zawadzki”, „Mirski”, „Mirek”, „Galma”, „Wojtek”, „Kozłowski”. Zob. S. Ko stane cki, Mirosław Zdziarski (1892-1939), „Rocznik Mazowiecki” 1969, t. II, s. 309-339; E. Krasucki, W drodze między Warszawq a Moskwa. Typowy życiorys przedwojennego polskiego komunisty na przykładzie losów Mirosława Zdziarskiego (1892-1937) [w:] Komuniści w międzywojennej Warszawie, red. E. Kowalczyk, Warszawa 2014, s. 111-136; AAN, Zbiór akt osobowych działaczy ruchu robotniczego 1918-1990, sygn. 297/II - 1682, Mirosław Zdziarski, k. 21-25; RGASPI, f. 496, op. 252, d. 501, Teczka osobowa Mirosława i Zinaidy Zdziarskich, Autobiografia Mirostawa Zdziarskiego, 5 XI 1928, k. 137-138. 
legalnik u Botwinów. Była to rodzina wyjątkowo sympatyczna. Panowała tam straszna bieda; była to liczna rodzina - kilka sióstr, dwóch braci. Naftali Botwin, był to niepozorny, milczący, ale bardzo oddany towarzysz z młodzieży

- wspominał po latach Radkiewicz ${ }^{29}$.

Według relacji kolegi z organizacji, Wojciecha Atłasa, Botwin

[...] wyróżniał się aktywnością i takimi cechami charakteru jak: poczucie odpowiedzialności, energia, zręczność konspiratora, hart i opanowanie. Był znany i ceniony w szerokich kręgach młodzieży lwowskiej [...] Przy każdej pracy i w każdej sytuacji cechował go poważny humor, a w rozmowie wplatał zawsze uszczypliwe uwagi o charakterze politycznym. Nie śmiał się jednak przy tym. W twarzy i w oczach miał jakąś zaciętość i upór. Nie był nigdy w nastroju beztroskiej wesołości. W ruchach był raczej powolny ${ }^{30}$.

Z kolei jego rówieśniczka i bliska współpracowniczka o pseudonimie „Hela” (Blima Finkielsztejn) opisała go następująco: „Natka znałam od dziecka, kiedy był jeszcze gazeciarzem. Potem pakunki nosił z dworca. [...] Najwięcej znałam go ze związku [...] Sam był wzrostu małego, krępy, nogi kabłąkowate od angielskiej choroby [...] On był wesoły i kpiarz porządny" ${ }^{\prime 31}$. Podkreśliła także, iż miał mocny głos i lubił śpiewać. Porównanie obu tych charakterystyk pozwala wywnioskować, iż opinie Atłasa zostały odpowiednio uformowane, aby nadać Botwinowi właściwe mu propagandowo cechy, które były wielokrotnie powtarzane oraz koloryzowane, aby podkreślić jego zasługi i heroizm. Wiązało się to z postulatem socjalistycznego dydaktyzmu.

W tych okolicznościach trudno oprzeć się wrażeniu, że Radkiewicz wydał swego przyjaciela, udzielającego mu gościny we własnym domu, na niechybną śmierć. Dlaczego polecił akurat jego? Czy kierował się przy tym wyłącznie pobudkami ideowymi? Przecież równie dobrze i on mógł wykonać wyrok partii. Dlaczego to właśnie on wybrał Botwina? Jednakże aby odkryć jego rolę w tej aferze kryminalnej, musimy podjąć próbę rekonstrukcji przeszłych wydarzeń w szerszym kontekście historycznym. Jest to zagadnienie niezwykle skomplikowane, pełne białych plam i niejasności. Dlatego wciąż czeka ono na zbadanie przez historyków.

Według innych relacji, bardziej popularnych, Botwin sam miał zgłosić swą kandydaturę. Jak podał Wojciech Atłas:

Do Lwowa przyjechał także przedstawiciel bratniej organizacji z Warszawy [tj. Zdziarski M.P.]. Przyjechał z wyrokiem na Cechnowskiego i natychmiast zwrócił się o pomoc w tej sprawie, przede wszystkim do koła młodzieżowego pracowników przemysłu skórzanego [...] Zabrał natychmiast głos Botwin. Uśmiechając się i nie patrząc na nikogo, jakby wstydliwie, oświadczył, że on uprzedza wszystkie wnioski i sam podejmuje się wykonania tego wyroku na prowokatorze [...] Przerywając przewlekającą się ciszę delegat Partii podszedł do Botwina

29 AAN, Zbiór akt osobowych działaczy ruchu robotniczego 1918-1990, sygn. 689, Botwin Naftali, O Naftalim Botwinie, k. 36.

${ }^{30}$ AAN, Zbiór akt osobowych działaczy ruchu robotniczego 1918-1990, sygn. 689, Botwin Naftali, W. Atłas, Towarzysz Botwin, k. 13.

31 Cyt. za: J. Prajs, Relacja o śmierci prowokatora. Na podstawie opowiadań Bronisławy Wajnberg, „Życie Literackie” 1958, r. VIII, nr 49 (359), s. 1. 
i ująwszy w obydwie ręce jego dłoń powiedział cicho: „Dziękuję, dziękuję w imieniu całego walczącego proletariatu"32.

Jest to wersja nieprawdopodobna, zupełnie epicka, ale ukazuje chwyt propagandowy podkreślający odwagę „bohatera” jako ochotnika i patos całej sytuacji.

Wciąż jednak nasuwa się pytanie: a jak się to wszystko zaczęło? Opowiedziała o tym „Hela” (Blima Finkielsztejn): „Więc tak: Przyszedł do mnie Natek, jako «Filip» z organizacji (takie miał pseudo): Z tobą ma się zobaczyć «Stanisław». Wieczorem o ósmej masz być na Wysokim Zamku koło lwów i masz być ubrana jak do ślubu"33. Kim był ów „Stanisław”? To Mirosław Zdziarski. „Już wtedy był szyszką. Członek KC. Bardzo go organizacja lubiła" ${ }^{34}$. Botwin występował tu wyłącznie w roli dostarczyciela wiadomości od Zdziarskiego, jednorazowego łącznika z ramienia komunistycznej młodzieżówki. Nie został on jednak wtajemniczony w planowaną akcję.

Następnie była łączniczka zrelacjonowała swoją rozmowę ze Zdziarskim, która dotyczyła warszawskiego zamachu na Cechnowskiego, aresztowania trzech towarzyszy, a wreszcie planu zgładzenia agenta defensywy we Lwowie: „Tym razem chce sypnąć KPZU i rozbić okręg lwowski. Znowu pójdą areszty towarzyszy [...] Jeśli zgładzimy Cechnowskiego, to będzie znak, że szło tylko o niego, a nie o nikogo innego. To uratuje towarzyszy [...] My nikogo nie zabijamy. My nie jesteśmy za indywidualnym terrorem”35 - usprawiedliwiał decyzję Zdziarski. Zadaniem „Helki” było śledzenie każdego kroku prowokatora we Lwowie.

Opowiedziała ona także o Stanisławie Radkiewiczu, nie znając jednak jego tożsamości. „Nazajutrz rano [24 lipca, piątek - M.P.] zapoznał mnie Stanisław ze Zbyszkiem [tj. Radkiewiczem - M.P.] i Bolkiem. Nigdy przedtem ich nie widziałam. Zauważyłam, że Zbyszek to inteligent, a Bolko robotnik. Bolko miał broń. Miało być tak: ja mam chodzić za Cechnowskim, mam wszystko przekazywać Zbyszkowi, a on Bolkowi. Bolko ma to zrobić. Bolko miał broń”36. Łączniczka śledziła więc Cechnowskiego od piątku, kiedy został jej pokazany przez Zdziarskiego.

W sobotę rano poszłam na podpunkt ze Zbyszkiem, jak było umówione. Zastałam tam również Stanisława. Mówię, jak wszystko było: restauracja, bilard, Rejtana. I o tym, że wsiadł do dorożki [...] A teraz słuchajcie - mówi do mnie i Zbyszka - dzisiaj wieczorem on ma być w teatrze. To jest pewne. Będziecie czekać, aż wyjdzie z teatru. Musicie na jedno uważać - czy jest sam. Jeżeli blisko koło niego ktoś będzie, strzelać nie wolno. To pamiętajcie. Nie wolno postrzelić innej osoby. Jak wyjdzie sam i oddali się trochę od wychodzących z teatru, Bolko ma podejść $\mathrm{z}$ rewolwerem, a wy macie zniknąc ${ }^{37}$.

32 AAN, Zbiór akt osobowych działaczy ruchu robotniczego 1918-1990, sygn. 689, Botwin Naftali, W. Atłas, Towarzysz Botwin, k. 18.

33 Cyt. za: J. Prajs, op. cit., s. 1.

34 Ibidem.

35 Ibidem, s. 6.

36 Ibidem, s. 7.

37 Ibidem. 
Jednakże okazało się, że ów tajemniczy „Bolko” stchórzył i uciekł z miasta do Gródka Jagiellońskiego, zabierając z sobą broń ${ }^{38}$. I tutaj dopiero pojawił się Naftali Botwin jako osoba, która miała zastąpić „Bolka” w wykonaniu wyroku Partii. Niestety do dziś nie wiadomo, kto ukrywał się pod tym pseudonimem. Z relacji Finkielsztejn wynika natomiast, iż „Zbyszek” również miał być obecny przy planowanym zamachu: „Nie ma Bolka, nie ma Zbyszka. To było straszne"39.

W tej oto sytuacji Zdziarski przekazał Radkiewiczowi podjęcie decyzji wytypowania kolejnego egzekutora, a ten wybrał Botwina.

Trzeba było z nim [Botwinem - M.P.] pogadać. Wobec tego, że termin pobytu Cechnowskiego był bardzo ograniczony (przyjechał on tylko na proces jako świadek), trzeba więc było liczyć na dwa-trzy dni najwyżej. Od razu poleciałem do Botwina, wziąłem go na bok i opowiedziałem mu o tej sprawie. On bez wahania wyraził zgodę, ale powiedział, że nie ma pistoletu, ani doświadczenia w strzelaniu, nigdy nie strzela1 ${ }^{40}$

- ciągną̧ swą relację „Zbyszek”.

„W niedzielę Botwin wyjechał z drugim towarzyszem do Gródka Jagiellońskiego, gdzie dopiero otrzymał od swojego znajomego [tow. «Bolka»-M.P.] rewolwer"41. Zaraz po powrocie udał się do „Helki”, przekazując zawiniątko z bronią. Pojawił się kolejny problem, a mianowicie Botwin nie potrafił strzelać. Potrzebny był nauczyciel, który odbył przeszkolenie wojskowe. Takiego człowieka wskazała „Helka”, a był nim Józef Reiter ${ }^{42}$.

$Z$ powyższych relacji możemy wywnioskować, że do soboty wieczorem (25 lipca 1925 r.) nie było mowy o bezpośrednim zaangażowaniu Botwina jako potencjalnego egzekutora wyroku na Cechnowskim. Taka opcja pojawiła się dopiero w niedzielę, kiedy zajął miejsce tajemniczego „Bolka” w grupie osób przygotowujących zamach. Zaangażował go właśnie Radkiewicz. Wniosek nasuwa się sam: młody Radkiewicz musiał cieszyć się poważaniem i sympatią ze strony kierownictwa partii, skoro to jego poproszono o wskazanie zaufanego kandydata na egzekutora.

Poszedłem z tym wszystkim do Zdziarskiego. Nie wiem, jak on zdobył pistolet, ale dał mi go wraz z kilkunastoma nabojami. Ja powiedziałem Botwinowi, żeby poszedł za park (Kościuszkowski czy Stryjski, już tego nie pamiętam), tam były wąwozy... «Idź, poćwicz troszkę» - powiedziałem $\mathrm{mu}^{43}$.

Radkiewicz nie wspomniał o obecności osób trzecich, jednakże wiemy, że nie byli wtedy sami.

Bezpośredni uczestnik tych wydarzeń, Józef Reiter, relacjonował:

38 AAN, Zbiór akt osobowych działaczy ruchu robotniczego 1918-1990, sygn. 689, Botwin Naftali, J. Reiter, Naftali Botwin ps. „Ćwinek”, ,Tulu”. Garść wspomnień, Warszawa, 30 IV 1960, mps, k. 30.

39 Cyt. za: J. Prajs, op. cit., s. 1.

40 AAN, Zbiór akt osobowych działaczy ruchu robotniczego 1918-1990, sygn. 689, Botwin Naftali, O Naftalim Botwinie, k. 36-37.

41 AAN, Zbiór akt osobowych działaczy ruchu robotniczego 1918-1990, sygn. 689, Botwin Naftali, W. Atłas, Towarzysz Botwin, k. 19.

42 Zob. J. Prajs, op. cit., s. 8.

43 AAN, Zbiór akt osobowych działaczy ruchu robotniczego 1918-1990, sygn. 689, Botwin Naftali, O Naftalim Botwinie, k. 37. 
[...] o godz. 10-ej rano „Hela” skontaktowała mnie z dwoma towarzyszami. Spotkanie odbyło się na ulicy, obok tzw. starego cmentarza żydowskiego przy ul. Szpitalnej. Jeden z tych towarzyszy był wysokiego wzrostu, blondyn, w toku rozmowy z nim zauważyłem, że ma niebieskie oczy, twarz była pełna, owalna. Dopiero po wojnie dowiedziałem się, że był to M. Zdziarski. Obecny przy naszej rozmowie drugi towarzysz był również wysoki, nieznacznie niższy, ciemny szatyn, o szczupłej twarzy i z wyglądu nieco młodszy ${ }^{44}$.

Owym drugim ,towarzyszem” był Stanisław Radkiewicz. Zdziarski przyniósł wówczas pistolet, przekazany wcześniej przez Botwina. „Stary grat, mauzer bębenkowy, pamięta jeszcze młodość Franciszka Józefa, siedmiostrzałowy"45.

W niedzielę wieczorem, ok. 21, odbyło się spotkanie na Wałach Hetmańskich, obok pomnika Sobieskiego ${ }^{46}$.

Formalnie grupa, której zadaniem było wykonanie wyroku partyjnego na Cechnowskim, składała się z czterech osób: „Hela” - utrzymywała stały kontakt ze Zdziarskim za pośrednictwem towarzysza [tj. Radkiewicza - M.P.], którego widziałem na spotkaniu ze Zdziarskim; w ten sposób otrzymywaliśmy dokładne informacje nieomal o każdym kroku Cechnowskiego, gdy tylko ukazywał się na ulicy; Naftali Botwin, ów towarzysz, który wówczas nie przybył w ogóle, i ja ${ }^{47}$.

Jak wyznał dalej Reiter:

Zaproponowałem, ażeby u wylotu ulicy Trybunalskiej (przy ul. Rutowskiego) przygotować dorożkę i po wykonaniu wyroku umożliwić Botwinowi ucieczkę. Zdziarski wytłumaczył, że jest to niepotrzebne i poparł to dwoma argumentami: Po pierwsze, że taka ucieczka może się nie udać, przytem może dojść do strzelaniny i niepotrzebnych ofiar, a do tego nie wolno dopuścić. Po drugie, Botwin nie ma ukończonych dziewiętnastu lat. Nawet, jeśli sąd skaże go na śmierć, to z uwagi na niepełnoletność zostanie ułaskawiony i wyrok zostanie mu zamieniony na dożywocie, a po tym postaramy się, by został wymieniony przez Związek Radziecki ${ }^{48}$.

Stanowisko Zdziarskiego opierało się na mylnym przekonaniu o niepełnoletności Botwina, tymczasem miał on już ukończone 20 lat. W tym miejscu napotykamy także rozbieżności czasowe odnoszące się do dnia, w którym odbyła się lekcja strzelania. Zapewne były one spowodowane zbyt dużym dystansem czasowym dzielącym omawiane wydarzenia od wspomnień, co powoduje, że te nie są już tak dokładne. „Tak krótką lekcję strzelania odbyliśmy w trójkę: tow. Botwin, tow. Finkielsztejn i ja w lesie Hołoska obok sanatorium ${ }^{49}[. .$.$] i tam w kilku słowach wyjaśniłem Botwinowi$ elementarne zasady celowania. Przy okazji Botwin oddał jeden strzał do bliskiego

${ }^{44}$ AAN, Zbiór akt osobowych działaczy ruchu robotniczego 1918-1990, sygn. 689, Botwin Naftali, J. Reiter, Naftali Botwin ps. „Ćwinek”, „Tulu”. Garść wspomnień, k. 29.

45 Cyt. za: J. Prajs, op. cit., s. 8.

46 AAN, Zbiór akt osobowych działaczy ruchu robotniczego 1918-1990, sygn. 689, Botwin Naftali, J. Reiter, Krótkie wspomnienie o moim zetknięciu się z tow. Naftalim Botwinem (Ćwinek Tulu), Szczecin, 26 IV 1950, mps, k. 8.

47 AAN, Zbiór akt osobowych działaczy ruchu robotniczego 1918-1990, sygn. 689, Botwin Naftali, J. Reiter, Naftali Botwin ps. „Ćwinek”, ,,Tulu”. Garść wspomnień, k. 30-31.

48 AAN, Zbiór akt osobowych działaczy ruchu robotniczego 1918-1990, sygn. 689, Botwin Naftali, J. Reiter, Naftali Botwin ps. „Ćwinek”, „Tulu”. Garść wspomnień, k. 31.

49 AAN, Zbiór akt osobowych działaczy ruchu robotniczego 1918-1990, sygn. 689, Botwin Naftali, J. Reiter, Naftali Botwin ps. „Ćwinek”, ,Tulu”. Garść wspomnień, k. 32. 
pnia drzewnego. Na tym polegało całe przeszkolenie strzeleckie Botwina" ${ }^{50}$. Zgodnie ze słowami „Heli” owo szkolenie odbyło się późnym wieczorem w niedzielę 26 lip$\mathrm{ca}^{51}$, natomiast według Reitera rankiem 27 lipca.

Wypowiedź Radkiewicza pozwala natomiast wywnioskować, że Botwin ćwiczył w niedzielę, gdyż w poniedziałek od samego rana cała, nadzorowana przez niego, grupa była już gotowa do działania.

Dość na tym, że on [tj. Botwin - M.P.] był gotów i na drugi dzień $[27$ lipca, poniedziałek M.P.] umówiliśmy się ze Zdziarskim na Wałach Hetmańskich. Botwin też był niedaleko. Z tych wałów było widać akurat bramę sądów, do której wszedł Cechnowski. Wtedy Zdziarski go nam pokazał; Cechnowski był wysoki, w brązowym ubraniu. W ten sposób Botwin go poznał. Chodziło teraz o wybranie odpowiedniego momentu i sposobu ${ }^{52}$.

W poniedziałek zamach został udaremniony przez niespodziewany hałas, który spowodował ukrycie się Cechnowskiego i zgubienie jego tropu.

[...] 27 lipca otrzymaliśmy od tow. Zdziarskiego poprzez tow. Finkielsztejn zlecenie następującej treści: «Albo we wtorek wykonane będzie zlecenie albo trzeba będzie z tego zrezygnować». Zakomunikowano to nam jako stanowisko KC. Wiedzieliśmy już, że Cechnowski będzie 28 lipca 1925 r. zeznawał przed południem przed sądem jako świadek/był to proces «Sztajgera»» ${ }^{53}$.

„Na dzień następny [wtorek - M.P.] razem z Botwinem wyizolowaliśmy Zdziarskiego i czekaliśmy na ławeczkach na Cechnowskiego. Postanowiliśmy wybrać nie ten moment, kiedy Cechnowski wejdzie do sądu, ale kiedy wyjdzie" ${ }^{54}$ - relacjonował Radkiewicz. Natomiast Reiter dostarczył więcej szczegółów o przebiegu zorganizowanego zamachu: „O godz. 11 ustawiliśmy się przy placu Halickim u wylotu ul. Batorego, skąd Cechnowski udawał się przez plac Halicki - albo do urzędu wojewódzkiego ul. Wałową - albo ul. Halicką do «Naftuły» na obiad"s5.

Ja znajdowałem się przy placu Halickim na rogu ul. Halickiej. Nasz plan był taki: w wypadku, gdyby Cechnowski udał się do urzędu ul. Wałową, idziemy za nim i dochodzimy do niego w górnej części ulicy, gdzie jest mniejszy ruch; gdyby zaś poszedł do restauracji, Botwin idzie za nim bezpośrednio aż do ul. Trybunalskiej i tam strzela, ja miałem przejść ul. Rutkowskiego i przyjść naprzeciw Cechnowskiemu - podał $\operatorname{Reiter}^{56}$.

Wszystkie role były podzielone, ale to Radkiewicz nadzorował, aby akcja została przeprowadzona zgodnie z planem.

50 AAN, Zbiór akt osobowych działaczy ruchu robotniczego 1918-1990, sygn. 689, Botwin Naftali,

J. Reiter, Krótkie wspomnienie o moim zetknięciu się z tow. Naftalim Botwinem..., k. 8.

${ }_{51}$ Zob. J. Prajs, op. cit., s. 8.

52 AAN, Zbiór akt osobowych działaczy ruchu robotniczego 1918-1990, sygn. 689, Botwin Naftali, O Naftalim Botwinie, k. 37.

53 AAN, Zbiór akt osobowych działaczy ruchu robotniczego 1918-1990, sygn. 689, Botwin Naftali,

J. Reiter, Krótkie wspomnienie o moim zetknięciu się z tow. Naftalim Botwinem..., k. 9.

${ }^{54}$ AAN, Zbiór akt osobowych działaczy ruchu robotniczego 1918-1990, sygn. 689, Botwin Naftali, O Naftalim Botwinie, k. 37.

55 AAN, Zbiór akt osobowych działaczy ruchu robotniczego 1918-1990, sygn. 689, Botwin Naftali,

J. Reiter, Naftali Botwin ps. „Ćwinek”, „Tulu”. Garść wspomnień, k. 32.

56 Ibidem, k. 33. 
Rzeczywiście on wyszed $\nmid$ - mniej więcej w porze obiadowej - w asyście dwóch ludzi i szedł w kierunku wąskiej uliczki, która tamtędy przechodziła. Wtedy Botwin, nie mówiąc słowa, podniósł się i poszedł za nim. Ja zostałem na swoim miejscu i tylko obserwowałem go z daleka. Po pewnym czasie usłyszałem strzał; oczywiście trzeba było uciekać... Dopiero później, wieczorem, wyszły nadzwyczajne dodatki gazet $\mathrm{z}$ wiadomościami o zamachu - i o tym, że „sprawca został ujęty”, a Cechnowski nie żyje ${ }^{57}$

- relacjonował Radkiewicz.

„Po godzinie 13-tej z gmachu sądu wyszła cała świta. W otoczeniu cywilnych 4-ch osób i 3-ch policjantów szedł Cechnowski środkiem jezdni. Wszyscy podeszli do rogu ul. Wałowej, tu Cechnowski pożegnał się z dwoma cywilami, a sam skierował się wprost ul. Halickiej"58. Według relacji Botwin przed oddaniem strzału, w odległości kilku kroków od ofiary, krzyknął: „Śmierć prowokatorom!”. Cechnowski zginął na miejscu ${ }^{59}$. Jak podaje historiografia: 28 lipca 1925 roku Naftali Botwin zastrzelił Józefa Cechnowskiego, który przybył do Lwowa pod nazwiskiem: Józef Celiński. Zamach miał miejsce ok. godz. 13, po opuszczeniu przez Cechnowskiego gmachu sądu, w którym składał zeznania jako świadek w tzw. procesie przeciwko Jaegerowi i towarzyszom (zwłaszcza Danielowi Pańczyszynowi) ${ }^{60}$, komunistom oskarżonym o organizację zamachu terrorystycznego na prezydenta ${ }^{61}$. Orzeczenie lekarza medycyny sądowej złożone na rozprawie brzmiało: „Cechnowski otrzymał dwa strzały. Pierwszy był śmiertelny - trafił w samo serce" ${ }^{\prime 62}$. „Z uwagi na to, że towarzysz strzelił do Cechnowskiego niemal na progu restauracji, dwaj agenci policji kryminalnej (nazwiska Mulik i Malawski), którzy aresztowali tow. Botwina, wprowadzili go natychmiast do korytarza restauracji" ${ }^{63}$. Obaj policyjni wywiadowcy za schwytanie i rozbrojenie Botwina otrzymali premię w wysokości 100 zł oraz nominację do odznaczenia ich Krzyżem Zasługi ${ }^{64}$. Natomiast Cechnowskiego pochowano w Warszawie na koszt państwa jako zasłużonego „byłego funkcjonariusza policji państwowej" ${ }^{65}$.

„Gazeta Lwowska” podała podobną, ale bardziej sugestywną wizję zamachu:

57 AAN, Zbiór akt osobowych działaczy ruchu robotniczego 1918-1990, sygn. 689, Botwin Naftali, O Naftalim Botwinie, k. 37-38.

58 AAN, Zbiór akt osobowych działaczy ruchu robotniczego 1918-1990, sygn. 689, Botwin Naftali,

J. Reiter, Krótkie wspomnienie o moim zetknięciu się z tow. Naftalim Botwinem..., k. 9.

59 AAN, Zbiór akt osobowych działaczy ruchu robotniczego 1918-1990, sygn. 689, Botwin Naftali, J. Reiter, Naftali Botwin ps. „Ćwinek”, „Tulu”. Garść wspomnień, k. 34.

60 Jaeger i towarzysze przed sądem, „Kurier Lwowski” 1925 (26 VII), nr 173, s. 1; Pańczyszyn placze się w zeznaniach, „Gazeta Poranna. Ilustrowany Dziennik Informacyjny Wschodnich Kresów” 1925, nr 7496, s. 1.

${ }_{61}$ Por. H. Cimek, L. Kieszczyński, Komunistyczna Partia Polski 1918-1938, Warszawa 1984.

62 AAN, Zbiór akt osobowych działaczy ruchu robotniczego 1918-1990, sygn. 689, Botwin Naftali, J. Reiter, Naftali Botwin ps. „Ćwinek”, „Tulu”. Garść wspomnień, k. 34.

63 AAN, Zbiór akt osobowych działaczy ruchu robotniczego 1918-1990, sygn. 689, Botwin Naftali,

J. Reiter, Naftali Botwin ps. „Ćwinek”, „Tulu”. Garść wspomnień, k. 34.

${ }^{64}$ Zob. Echa morderstwa, „Gazeta Lwowska” 1925 (1 VIII), nr 174, s. 2.

65 Po krwawem morderstwie komunistycznym, „Kurier Lwowski” 1925 (1 VIII), nr 178, s. 1. 
Morderca Naftali Botwin [...] 21-letni chłopak, robiący wrażenie kilkunastoletniego wyrostka, czatował na Cechnowskiego na ławce skweru przy pl. Halickim [...] by na skręcie z Rynku w ul. Trybunalską wpakować mu w plecy z odległości czterech kroków dwie kule większego Brauninga [...] Opinia publiczna domaga się energicznego thumienia bohaterów w guście Botwina $^{66}$.

Natomiast „Słowo Polskie” skomentowało zamach jako „łańcuch akcji komunistyczno-terrorystycznej, zakrojonej na wielką miarę, a będącej uzupełnieniem działalności dywersyjno-bandyckiej watah bolszewickich na naszej granicy wschodniej" ${ }^{67}$.

W tej sytuacji KPP wydało odezwę, którą szeroko rozpowszechniano:

Robotnicy i Chłopi! Do walki w obronie Botwina! Występujcie masowo przeciw sądowi doraźnemu nad bohaterami proletariatu. Czyn Botwina niechaj umocni w nas wolę walki z burżuazyjnym systemem prowokacji, walki o obalenie panowania burżuazji, o dyktaturę proletariatu. Precz ze zdrajcami i prowokatorami! Niech żyje bohater czynnej walki z prowokacją - Botwin! ${ }^{68}$.

Wkrótce duża tajna drukarnia KPZU przy ulicy Pułaskiego $15^{69}$, publikująca te odezwy, została wykryta przez policję, a zapasy gotowych ulotek apoteozujących Botwina skonfiskowano. Poza tym aresztowano wielu komunistów, łapiąc ich na gorącym uczynku kolportażu odezw antypaństwowych ${ }^{70}$. Aresztowano m.in. kierującego wspomnianą drukarnią technika, Hilela Kranza (posiadającego fałszywy paszport na nazwisko Henryk Horsowski), oraz jego narzeczoną, kolporterkę Salę Rosenmann, a łącznie zatrzymano 21 osób.

W wyniku zakrojonego na szeroką skalę dochodzenia śledczego zlikwidowano wiele komórek KPZU, także poza terenem Lwowa. W lipcu 1925 roku zlikwidowano kilka kół Komunistycznego Związku Młodzieży Zachodniej Ukrainy (ZMKZU) i aresztowano ok. 16-17 osób ${ }^{71}$.

\section{PRZEBIEG PROCESU NAFTALEGO BOTWINA I JEGO SPOŁECZNO-POLITYCZNE REPERKUSJE}

Śledztwo w sprawie Botwina szło w dwóch kierunkach: co do podłoża zabójstwa i jego motywów. ,Drugi tor, po którym toczą się policyjne dochodzenia - jest stwierdzenie ewentualnej łączności dokonanego mordu z chęcią wywarcia wpływu ze

66 Cyt. za: Mord polityczny, „Gazeta Lwowska” 1925 (30 VII), nr 172, s. 3; Terroryści komunistyczni morduja!, „Kurier Lwowski” 1925, nr 176, s. 1.

67 Po zbrodni, ,Słowo Polskie” 1925, nr 206, s. 1.

68 AAN, Zbiór akt osobowych działaczy ruchu robotniczego 1918-1990, sygn. 689, Botwin Naftali, W. Atłas, Towarzysz Botwin, k. 21-22.

${ }^{69}$ „Kurier Lwowski” 1925 (8 VIII), nr 184, s. 1, podaje, że drukarnia mieściła się przy ul. Poniatowskiego.

70 Wykrycie olbrzymiej, tajnej drukarni komunistycznej we Lwowie, „Kurier Lwowski” 1925 (8 VIII), nr 184, s. 1.

71 „Słowo Polskie” 1925 (11 VIII), nr 217, s. 3; „Słowo Polskie” 1925 (26 VIII), nr 232, s. 8. 
strony komunistów na toczący się obecnie proces Jaegera i towarzyszy"72. Policja polityczna szybko doszła do wniosku, iż Botwin wykonywał rozkaz wyższych instancji władz partyjnych, kierując się pobudkami samoobrony wewnętrznej w ramach partii komunistycznej wobec konfidentów, zdrajców i prowokatorów. W trakcie toczącego się procesu, wobec nieustannych przesłuchań oraz stosowanej przemocy, Botwin groził rozpoczęciem strajku głodowego ${ }^{73}$. Poza tym policja zatrzymała członków jego rodziny (matkę, siostry i brata - kelnera) oraz kilku żydowskich komunistów z KPZU, którzy znaleźli się w pobliżu miejsca zbrodni. Jednakże, jak donosiła prasa lwowska, toczące się śledztwo nie przynosiło większych efektów odnośnie do współwinnych zamachu na Cechnowskiego ${ }^{74} .1$ sierpnia 1925 roku przybył nawet z Warszawy specjalny prokurator, delegat ministra sprawiedliwości, aby nadać bieg całemu dochodzeniu.

5 sierpnia 1925 roku Botwin stanął przed sądem doraźnym. Endecka „Rzeczpospolita” w sprawozdaniu z sądu pisała: „Na ławie oskarżonych siedzi szczupły, niewielki [...] Naftali Botwin. Twarz blada, spokojna. Nie zdradza żadnego wzruszenia. Robi wrażenie człowieka dość inteligentnego - jednak wyrobionego w jednym kierunku"75. Botwin na pytanie prokuratora, dlaczego dokonał zamachu na Cechnowskiego, a nie na inspektora Piątkiewicza, chociaż ten ostatni jest groźniejszy dla partii komunistycznej, odpowiedział, że „Piątkiewicz jest urzędnikiem policyjnym i wykonuje swoje obowiązki, Cechnowski zaś zdradził partię, był prowokatorem" "76. Powiedział także, iż otrzymał rozkaz zabicia Cechnowskiego w poniedziałek 27 lipca, zaś we wtorek miał on zostać ostatecznie wykonany. Jednakże nie zdradził nazwisk żadnych współpracowników, twierdząc, iż działał samodzielnie, wykonując polecenie od „nieznajomego osobnika z partii”: „Partia wydała rozkaz i honor partyjny wymagał, abym go wykonał"'77. Z ławy adwokackiej padło wówczas porównanie czynu Botwina do zamachów terrorystycznych organizowanych przez bojówki PPS w 1905 roku, które wywołało ogromną falę oburzenia opinii publicznej ${ }^{78}$.

Podczas rozprawy sądowej Botwin, kreśląc losy swego życia, zeznał:

Ojca swego nie pamiętam, odumarł mnie, gdy miałem zaledwie 3 lata. Pozostało nas 8 sierot. Matka utrzymywała nas wszystkich, lecz w ostatnich latach ja utrzymywałem całą rodzinę. Przez nędzę w domu wcześnie wystąpić musiałem ze szkoły [...] zostałem szewcem. W 1923 wstąpiłem do partii komunistycznej. Stałem się komunistą, gdyż komunizm wskazuje drogę [...] do równości i szczęścia ${ }^{79}$.

W trakcie procesu toczył się spór prawniczy pomiędzy wybitnym polskim adwokatem żydowskiego pochodzenia, dr. Maurycym Axerem (1886-1942) $)^{80}$, a sądem,

72 Po dokonanym przez sow-terrorystów morderstwie, „Kurier Lwowski” 1925 (31 VII), nr 177, s. 1.

3 Dalszy przebieg śledztwa. Botwin grozi głodówka, „Gazeta Poranna” 1925 (1 VIII), nr 7496, s. 2.

Zob. Echa politycznego mordu, „Gazeta Lwowska” 1925 (2 VIII), nr 175, s. 3.

Zob. R. Juryś, Kulisy wielkiej prowokacji, Warszawa 1968, s. 169-170.

6 Zob. Proces Botwina we Lwowie, „Ilustrowana Republika” 1925, nr 10, s. 1.

7 Ibidem.

78 Zob. Oburzające porównanie, „Kurier Lwowski” 1925, nr 185, s. 1.

7 Cyt. za: L. Krzemień, op. cit., s. 186.

${ }^{80}$ Zob. E. Axer, Z pamięci, Warszawa 2006. 
gdyż obrońca dowodził, iż tow. Botwin na skutek niepełnych 18 lat nie podlega sądowi doraźnemu ${ }^{81}$. Niektóre dokumenty metrykalne wskazywały bowiem, iż urodził się on w 1908 roku. W tym celu Axer kontaktował się z żydowskim Urzędem Metrykalnym, a także z kancelarią prezydenta, ubiegając się o ułaskawienie. Jednakże urząd wydał oświadczenie, iż Botwin w lutym 1925 roku ukończył 20 lat, a wiek ten stanowił minimalną granicę wieku dla podsądnego w sądzie doraźnym. Wobec tego odrzucono argumenty obrońcy i skazano oskarżonego na karę śmierci przez rozstrzelanie. Ówczesny prezydent państwa Stanisław Wojciechowski nie skorzystał z prawa łaski.

Co do przeszłości Botwina stwierdzono, iż jest to niebezpieczny agitator komunistyczny, który od dawna już rozwijał ożywioną działalność wywrotową. On to niedawno w czasie demonstracji robotniczych odbywanych w Rynku, podniecał thumy do stawiania oporu posterunkowym. On pierwszy rzucił się na stojące w ulicy fury z węglem i pod jego komendą thum począł obrzucać organy bezpieczeństwa kawałami węgla ${ }^{82}$.

Joachim Ehrlich wspominał:

Dozorca więzienny pilnujący celi tow. Botwina opowiadał nam potem, że kiedy przyprowadzono do celi tow. Botwina zrozpaczoną i zalewającą się łzami matkę jego, tow. Botwin uspokajał ją mówiąc, że nie powinna płakać bo na jego miejsce staną inni towarzysze i prosił, ażeby zachowywała się jak matka rewolucjonisty. Tow. Botwin nie pozwolił sobie zawiązać oczu ${ }^{83}$. Przez cały czas wznosił okrzyki - zaśpiewał Międzynarodówkę. Drobny, wątły, niepozorny tow. Botwin wzbudził ogólny podziw nawet u wrogów. Dozorcy więzienni omawiając sprawę tow. Botwina między sobą nie mogli wyjść z podziwu, że w takim małym, wątłym chłopcu kryła się taka wielka siła i hart ${ }^{84}$.

Jako ideowy komunista odrzucił także posługę rabina. W ramach swego ostatniego życzenia Botwin zażądał 10 papierosów egipskich i butelki koniaku, a jego prośbę spełniono. Dnia 6 sierpnia 1925 roku o godz. 13.15 został rozstrzelany na podwórzu więzienia przy ulicy Kazimierzowskiej, nazywanego potocznie Brygidkami ${ }^{85}$. Ostatnimi słowami Botwina miał być okrzyk: „Niech żyje rewolucja!”»6.

Od dnia egzekucji odbywały się demonstracje komunistyczne i pielgrzymki do grobu zamachowca. Gdy manifestacje te nie ustawały, policja dokonywała aresztowań wśród ich uczestników. Komuniści zaopiekowali się członkami rodziny Botwina, którzy „,wyjechali do ZSRR, gdzie otrzymują wydatną pomoc na utrzymanie i kształcenie. A ulica, przy której jest poselstwo polskie w Moskwie, została nazwana

81 Po dokonanym przez sow-terrorystów..., s. 1.

82 Ibidem.

83 Sprawiedliwości stalo się zadość, „Kurier Lwowski” 1925, nr 184, s. 1.

84 AAN, Zbiór akt osobowych działaczy ruchu robotniczego 1918-1990, sygn. 689, Botwin Naftali, J. Ehrlich, Moje wspomnienia o towarzyszu Botwinie, mps, k. 27.

85 Renesansowy gmach został zbudowany w 1614 r. dla żeńskiego zakonu św. Brygidy, a po likwidacji zakonu w 1784 r. został zamieniony na więzienie. Po I wojnie światowej było to więzienie polityczne.

${ }^{86}$ Sprawiedliwości..., s. 1. 
ulicą im. Botwina. [...] A corocznie, w rocznicę śmierci Botwina, odbywały się wędrówki młodzieży do grobu jego, na którym składano czerwone kwiaty" ${ }^{\prime 7}$.

Po wykonaniu wyroku na Botwinie KC ZMK oświadczył, iż „zapłonie słońcem jego krew!", a dla uczczenia jego pamięci w nocy we Lwowie, w różnych punktach miasta, wywieszono 21 czerwonych sztandarów ${ }^{88}$. W pierwszą rocznicę jego stracenia na ulicy Słonecznej we Lwowie ${ }^{89}$ podmieniono tabliczki z nazwą ulicy i zjawiły się nowe z napisem: „ulica Naftalego Botwina”"90. W ten sposób dokonywano swoistej kanonizacji Botwina jako męczennika za sprawę socjalizmu. Jego heroizacji służyło nie tylko przypisywanie mu wybitnych cech, ale także celowe zaniżanie jego wieku do 17-18 lat.

21 sierpnia 1925 roku na stokach Cytadeli warszawskiej rozstrzelano poprzedników Botwina, tj. Hibnera, Kniewskiego i Rutkowskiego. Zatem sprawa Cechnowskiego pociągnęła za sobą śmierć siedmiu osób. Nabrała ogólnokrajowego rozgłosu. Raporty Ministerstwa Spraw Wewnętrznych od 27 lipca do 30 sierpnia 1925 roku notowały: „Sztandary, napisy, odezwy w związku ze straceniem Hibnera, Kniewskiego, Rutkowskiego i Botwina ukazały się w ogólnej ilości 175"91 m.in. w takich w miejscowościach, jak: Warszawa, Poznań, Łódź, Otwock czy Wilno, a także w innych miejscach, zwłaszcza na południowych i wschodnich ziemiach II Rzeczpospolitej.

Sprawa skazania czterech zamachowców przyniosła również reperkusje międzynarodowe o zasięgu globalnym. Nawet do Ambasady RP w Waszyngtonie wpływały rezolucje potępiające „biały terror” panujący w Polsce, wymierzony w klasę robotniczą ${ }^{92}$. Podobne protesty w Ambasadzie RP w Berlinie i innych placówkach konsularnych w dniach 19-21 sierpnia 1925 roku zgłaszały także niemieckie organizacje komunistyczne (m.in. Saska Partia Komunistyczna) oraz niemiecka Liga Obrony Praw Człowieka ${ }^{93}$.

„Kurier Poranny” z 23 sierpnia 1925 roku podawał informacje zaczerpnięte z przeglądu prasy francuskiej. Zwrócono uwagę zwłaszcza na wiadomości paryskiego dziennika „L'Humanite” z 20 sierpnia, dotyczące m.in. postanowienia rady municypalnej Bobigny odnośnie do nazwania jednej z ulic nazwiskiem Botwina. „Tabliczka tej ulicy będzie nosiła kompletny napis następujący: ulica Botwina, robotnika

87 AAN, Zbiór akt osobowych działaczy ruchu robotniczego 1918-1990, sygn. 689, Botwin Naftali, W. Atłas, Towarzysz Botwin, k. 24.

88 Zob. „Więzień Polityczny” 1926, II; „Więzień Polityczny” 1925, VIII-IX [za:] L. Krzemień, op. cit., s. $187-188$.

${ }^{89}$ Była to ulica zamieszkała w większości przez ludność żydowską. Przy ulicy Słonecznej 18 znajdował się dom Botwina.

90 Zob. L. Krzemień, op. cit., s. 188.

91 Ibidem.

92 Zob. AAN, Ambasada RP w Waszyngtonie, sygn. 2359, Wewnętrzna sytuacja polityczna w Polsce, nr 3907, 5 października 1925 r., Waszyngton, k. 23-24.

93 Zob. AAN, Ambasada RP w Berlinie, sygn. 392, Ruch komunistyczny. Protesty niemieckich organizacji komunistycznych oraz Ligi Obrony Praw Człowieka przeciw białemu terrorowi w Polsce, głównie przeciwko procesowi Łańcuckiego; straceniu Hibnera i towarzyszy oraz rozwiqzaniu Hromady i wyrokom śmierci we Lwowie. Raporty placówek polskich w Niemczech, odpisy rezolucji, teksty oskarżenia, korespondencja, wycinki prasowe, instrukcje MSZ, k. 33-98. 
- rewolucjonisty, ofiary białego terroru”94. Dziennik „Le Temps” przekazał natomiast, że kongres socjalistycznej partii francuskiej, zakończony 18 sierpnia, uchwalił „rezolucję protestu przeciw egzekucji Botwina w Polsce i przeciw prześladowaniom, których ofiarami są w Polsce i gdzie indziej działacze komunistyczni i socjalistyczni" ${ }^{95}$.

Protest wobec ,terroru w Polsce” podpisało ponad 50 wybitnych intelektualistów francuskich, a wśród nich tacy pisarze, jak m.in.: Louis Aragon, Henri Barbusse, Georges Duhamel i Romain Rolland. Uchwały protestacyjne podjął też międzynarodowy zjazd wolnomyślicieli w Paryżu. Opinia publiczna sprawiła, że zabrał głos również minister spraw zagranicznych Francji Aristide Briand oraz Albert Arthur Purcell, przywódca angielskich związków zawodowych i przewodniczący Międzynarodówki Amsterdamskiej. Globalna demonstracja solidarności z KPP i ZMKP spowodowała, że jeden z posłów stwierdził w Sejmie: „Nazwiska Hibnerów i Botwinów są na całym świecie bardziej znane niż nazwiska polskich ministrów!"’96.

Zamieszanie polityczne wokół zamachu na Cechnowskiego odniosło ambiwalentne skutki. Zaowocowało ono bowiem zaostrzeniem represji i falą aresztowań dokonanych przez aparat państwowy, a to z jednej strony umacniało nastroje antykomunistyczne, zaś z drugiej wywoływało opór i zapał rewolucyjny w międzynarodowym ruchu robotniczym ${ }^{97}$. Dnia 10 września 1925 roku aresztowano kolejnych działaczy KPZU, a także ZMK, m.in. Oskara Berkowicza ${ }^{98}$, który według zeznań Botwina - jako sekretarz Komitetu Okręgowego KPZU we Lwowie (od wiosny 1925 do 1930 r.) - miał być też zamieszany w zamach na Cechnowskiego. W kwietniu 1926 roku odbyła się seria rozpraw sądowych przeciwko 15 aresztowanym komunistom, w wyniku których $10 \mathrm{z}$ nich otrzymało kary więzienia w wymiarze od 10 miesięcy do 5 lat, zaś ten najwyższy wyrok przypadł Hilelowi Kranzowi. Natomiast Berkowicz otrzymał karę 1 roku więzienia ${ }^{99}$. W rezultacie licznych aresztowań KC ZMK Zachodniej Ukrainy we Lwowie został zlikwidowany w październiku 1925 roku $^{100}$. Z kolei 28 listopada 1925 roku aresztowano m.in. Adriana Hoszowskiego, instruktora KC KPZU we Lwowie ${ }^{101}$.

94 „Ulica Botwina” - w Bobigny. Kongres socjalistów francuskich o prześladowaniach w Polsce, „Kurier Poranny” 1925 (23 VIII), s. 18.

95 Ibidem.

96 „Więzień Polityczny” 1925, X-XI, nr 7-8 [za:] L. Krzemień, op. cit., s. 188.

97 Co ciekawe, w grudniu 1937 r. powstała nawet Kompania im. Naftalego Botwina, złożona z żydowskich wolontariuszy walczących w hiszpańskiej wojnie domowej. Wchodziła ona w skład Batalionu Brygad Międzynarodowych gen. Palafoxa. Jej organem prasowym było czasopismo zatytułowane „Botwin".

98 Zob. B. Gadomski, Berkowicz Oskar [w:] Stownik biograficzny..., s. 148-149.

99 „Słowo Polskie” 1926 (3 IV), nr 92, s. 7; „Słowo Polskie” 1926 (14 IV), nr 101, s. 8; „Słowo Polskie" 1926 (30 IV), nr 117, s. 7 [za:] G. Mazur, op. cit., s. 385.

100 J. Ławnik, Represje policyjne wobec ruchu robotniczego 1918-1939, Warszawa 1979, s. 192.

101 Centralne Państwowe Historyczne Archiwum Ukrainy we Lwowie (Centralnyj Derżawnyj Istorycznyj Archiw Ukrajiny u Lwowi, CDIA), fond 205, opis 1, sprawa 548, k. 34-50, 53-54; DALO, fond 1 , opis 11 , sprawa 61 , k. 14-15; fond 121 , opis 1 , sprawa 61 , k. 53-69; sprawa 62, k. 17-47 [za:] G. Mazur, op. cit., s. 385-386. 
Jednakże w samej KPP reperkusje zabójstwa prowokatora przyczyniły się do dyskusji na temat celowości tego rodzaju akcji. Jeszcze w sierpniu 1925 roku KC KPP podjął specjalną rezolucję dotyczącą organizowania zbrojnej samoobrony, a mianowicie: „Terror indywidualny jako środek walki politycznej usypia świadomość mas, stępia ich aktywność, rodząc w nich złudzenie, że ktoś zastąpi ich w walce z rządem burżuazyjnym i ustrojem kapitalistycznym" 102 .

IV Konferencja KPP w Moskwie (24 listopada - 23 grudnia 1925 r.) wskazywała zaś, że walka z prowokacją na drodze terroru była błędem. Niejednoznaczne stanowisko członków KPP wobec zaistniałych wydarzeń doskonale podsumował „Ignac” - Jan Lubieniecki: „Ja zgodzę się z tym, że nawet po śmierci nie należy wyjaskrawiać tego bohaterstwa, nie należy tworzyć ideologii, ale nie można mówić, że towarzysze ci popełnili czyny antypartyjne. Gdyby ci towarzysze żyli teraz, my byśmy zapewne urządzili sąd partyjny"103. Skrytykowano walkę na drodze indywidualnego terroru, ale jednocześnie wytyczne partyjnego kierownictwa nie pomniejszały społecznego uznania dla skazanych zabójców. Dobitnie świadczy o tym złożony im hołd oraz przyjęta rezolucja:

Niechaj każdy proletariusz, który walczy w szeregach armii rewolucyjnej albo do niej dopiero wstępuje, złoży uroczysty ślub, że w życiu swem i walce nie zapomni nigdy o Botwinie, Hibnerze, Kniewskim i Rutkowskim i że pomści ofiarę ich życia przez obalenie panowania burżuazyjnych katów, przez rozkucie z kajdan robotników i chłopów Polski1 ${ }^{104}$.

\section{MIT NAFTALEGO BOTWINA W POLSCE LUDOWEJ}

Wokół sprawy zamachu na prowokatora powstało mnóstwo legend i zagadek. Chociaż peerelowskie władze nawiązywały do postaci Botwina na przestrzeni niemal półwiecza swego istnienia, stawiając go na panteonie komunistycznych bohaterów jako wzór dla młodzieży socjalistycznej, to jednak nie doczekał się on żadnego ujęcia monograficznego ${ }^{105}$. Wydaje się to dziwne i intrygujące, skoro prasa pisała o nim zarówno z okazji rocznicy urodzin, jak i śmierci. Rolę jego współpracowników czy współorganizatorów zamachu na Cechnowskiego zawsze pomijano. Historiografia zupełnie zapomniała, czy też raczej celowo milczała o zaangażowaniu osób trzecich, pociągających za sznurki w całym tym wyreżyserowanym spektaklu, do

102 Cyt. za: Z rezolucji KC KPP w sprawie walki z prowokacja uchwalonej w pierwszej połowie sierpnia 1925 r. [w:] KPP: Uchwaty i rezolucje, red. J. Kowalski, F. Kalicka, Sz. Zachariasz, wstęp: J. Kowalski, t. II, Warszawa 1955, s. 253.

103 AAN, Protokół IV Konferencji KPP, sygn. 158/II-4/t. 9, Przemówienie tow. Ignaca, k.196.

104 AAN, Protokół IV Konferencji KPP, sygn. 158/II-4/t. 9, Rezolucja w sprawie świetlanej pamięci tow. Botwina, Hibnera, Kniewskiego i Rutkowskiego, k. 9.

105 Zob. obowiązujące w peerelowskich szkołach podręczniki do historii: Historia Polski 1864-1945. Materiaty do nauczania $w$ klasie XI, red. Ż. Kormanowa, Warszawa 1952; M. Dłuska, J. Schoenbrenner, Historia dla klasy IV, Warszawa 1953. 
których należeli Zdziarski i Radkiewicz. Botwin miał działać samotnie, jak przystało na bohatera-męczennika, poświęcającego się w imię dobra ogółu. Jak pisała w 1948 roku „Trybuna Robotnicza”: „Nie drgnęła ręka tow. Botwina, gdy spełniał misję, jaką powierzyła mu Partia" 106 .

W latach 1949-1950 powstała propagandowa powieść Tadeusza Brezy pt. Niebo i ziemia, w której wzorem dla młodych komunistycznych bohaterów był m.in. Naftali Botwin ${ }^{107}$. W 1952 roku „Głos Olsztyński”, oddając cześć jego pamięci, pisał, iż „Za taką Polskę, jaką mamy dzisiaj, oddał życie Naftali Botwin”"108. W 60. rocznicę urodzin pisano m.in.: „Pamięć o nim zagrzewała do walki pokolenia komunistów i została żywa po dzień dzisiejszy"109. W duchu marksizmu dokonywano sakralizacji całej tej afery: „Bohatersko szedł naprzeciw śmierci w przekonaniu, że ginie za świętą sprawę" ${ }^{110}$. To zjawisko doskonale ukazuje także, jak pamięć indywidualna kształtuje pamięć zbiorową, a wreszcie społeczną świadomość historyczną, która opiera się na pewnym zespole wyobrażeń o przodkach i przeszłości oraz ich upamiętnieniu.

\begin{abstract}
W wyobraźni współczesnych mu towarzyszy, w ich pisanych wspomnieniach utrwalił się taki obraz: drobny, wątły chłopiec z pistoletem w ręce podbiega do otoczonego szpiclami, groźnego prowokatora i celnym wystrzałem kładzie kres życiu i zbrodniczej działalności zdrajcy. I drugi obraz: postać młodzieńca stojącego przed plutonem egzekucyjnym wydaje się bardzo nikłą, ot, mały punkt wobec muru śmierci luf karabinowych. Ale głos skazanego brzmi dźwięcznie i nadspodziewanie silnie, kiedy wznosi okrzyk: „Niech żyje rewolucja! Niech żyje Polska socjalistyczna!”. Oczy zaś, których nie pozwolił sobie przesłonić, patrzą śmiało z jakąś niezwykłą wiarą i siłą... ${ }^{11}$
\end{abstract}

Ten komunistyczny święty, niczym socrealistyczny pomnik, miał być źródłem natchnienia i jednym z najważniejszych rewolucyjnych mitów, które były pieczołowicie propagowane przez władze. Przykładem tego rodzaju działalności była budowa pomników Hibnera, Rutkowskiego i Kniewskiego w Cytadeli w latach 1950-1952 ${ }^{112}$.

W tę apoteozę młodzieńca wpisuje się także czytany w peerelowskich szkołach wiersz napisany ku czci Botwina, pt. Na śmierć rewolucjonisty (1925), autorstwa Władysława Broniewskiego, a zwłaszcza jego fragment:

Ach, umierać nie będzie ciężko,

chociaż serce ma lat dwadzieścia-

nie złamane codzienną klęską,

dziesięć klęsk, dziesięć kul pomieści!

106 Zob. I. Orzechowski, op. cit., s. 5.

107 Publikowano ją w odcinkach na łamach „Dziennika Literackiego”; zob. T. Breza, Niebo i ziemia. Fragment z II tomu powieści, „Dziennik Literacki” 1950, R. IV, nr 36, s. 1-2.

108 Cyt. za: Człowieka - żal, prowokatora - nie, „Głos Olsztyński” 1950 (9-10 VIII), s. 3.

109 AAN, Zbiór akt osobowych działaczy ruchu robotniczego 1918-1990, sygn. 689, Botwin Naftali, S. Ludwińska, W 60-ta rocznicę urodzin, Warszawa, 8 II 1965 r., mps, k. 45.

110 Zob. I. Orzechowski, op. cit., s. 5.

111 AAN, Zbiór akt osobowych działaczy ruchu robotniczego 1918-1990, sygn. 689, Botwin Naftali, S. Ludwińska, W 60-rocznicę urodzin, k. 43.

112 AAN, Biuro Naczelnej Rady Odbudowy Warszawy i Rady Głównej Społecznego Funduszu Odbudowy Kraju i Stolicy w Warszawie, sygn. 215, Budowa pomników Hibnera, Rutkowskiego, Kniewskiego na Cytadeli. Kosztorys, wniosek inwestycyjny. 
Bo jest życie piękniejsze, nowe,

i żyć warto, i umrzeć warto!

Trzeba nieść, jak chorągiew, głowę,

świecić piersią kulami rozdartą,

trzeba umieć umierać pięknie,

patrzeć w lufy wzniesione śmiało!

Aż się podle zadziwi i zlęknie,

aż umilknie łoskot wystrzałów! ${ }^{113}$

Julia Prajs, czyli Brystygierowa ${ }^{114}$, podała, że plotki o okolicznościach śmierci Botwina - „to wszystko prawda”. W swym artykule w ,Życiu Literackim” z 1958 roku, pt. Relacja o śmierci prowokatora, powoływała się na zdaną jej ustną relację Bronisławy Wajnberg - Blimy Finkielsztejn (ur. 1907 r., zm. 6 maja 1985 r.). To ona była bowiem ową „Helką”, 18-letnią łączniczką między Zdziarskim, Radkiewiczem i Botwinem: „Mój brat odsiadywał wtedy w Brygidkach, widział przez kratę, jak Botwina prowadzili. Śpiewał. I brat mój za nim, z wszystkimi więźniami śpiewali: «Wyklęty powstań». I to prawda o tym, jak się zachowywał na sądzie" 115 . To właśnie Brystygierowa przyczyniła się do ożywienia pamięci o Botwinie, co pociągnęło za sobą szersze zainteresowanie Zakładu Historii PZPR innymi współpracownikami Botwina: Stanisławem Radkiewiczem i Józefem Reiterem.

\section{PODSUMOWANIE}

Do liczby upamiętnień sylwetki Botwina należy dodać jeszcze przykłady współczesne, świadczące o tym, że jego legenda trwa nawet w 2016 roku. Mit Botwina ma się całkiem dobrze i 91 lat po jego śmierci. Warto bowiem zauważyć, że w takich miastach, jak Ząbkowice Śląskie czy Pieszyce nadal istnieją ulice im. Naftalego Botwina. Co więcej, w Warszawie dzisiejsza ulica Eugeniusza „Dubańca” Bocheńskiego aż do 18 czerwca 1998 roku nosiła nazwę Naftalego Botwina, zaś we Wrocławiu taka ulica istniała do 17 października 2013 roku.

Powyższe fakty dobitnie dowodzą, iż sprawa zabójstwa Cechnowskiego przez Botwina wymaga przypomnienia, aby uświadomić społeczeństwu, kim właściwie był patron ich ulicy. Pamięć zbiorowa wymaga pod tym względem korekty historycznej, gdyż nadal pokutują w niej fałszywe wyobrażenia pielęgnowane przez władze komunistyczne na użytek socjalistycznej ,inżynierii dusz”. Upamiętnianie jest szczególnym rodzajem władzy nad pamięcią społeczną. Przysługuje ona wspólnocie,

113 Cyt. za: W. Broniewski, Na śmierć rewolucjonisty, w. 9-20 [w:] M. Urbanek, Broniewski. Miłość, wódka, polityka, Warszawa 2011, s. 76.

114 Julia Brystiger (1902-1975) - nauczycielka historii, dr filozofii, członkini KPZU, KPP, PPR i PZPR, funkcjonariuszka aparatu bezpieczeństwa Polski Ludowej o pseudonimach Luna, Daria, Ksenia, Maria, a następnie dyrektor V i III Departamentu MBP; redaktor w Państwowym Instytucie Wydawniczym o pseudonimie literackim: Julia Prajs (nazwisko panieńskie).

115 Zob. J. Prajs, op. cit., s. 1. 
a dzięki upamiętnieniu i zapomnieniu możliwa jest rekonstrukcja przeszłości, kształtowanie teraźniejszości oraz tworzenie przyszłości na drodze selekcji z dorobku pokoleń. Dlatego warto zainteresować się wydarzeniami z roku 1925 i dokonać ich rzetelnej analizy, aby wreszcie poznać całą prawdę o takich osobach, jak Naftali Botwin czy Stanisław Radkiewicz.

\section{BIBLIOGRAFIA}

\section{Dokumenty archiwalne}

\section{AAN, Akta sądów wojskowych, sygn. 427/II/1-88.}

AAN, Ambasada RP w Berlinie, sygn. 392, Ruch komunistyczny. Protesty niemieckich organizacji komunistycznych oraz Ligi Obrony Praw Człowieka przeciw białemu terrorowi w Polsce, głównie przeciwko procesowi Łańcuckiego; straceniu Hibnera i towarzyszy oraz rozwiazaniu Hromady i wyrokom śmierci we Lwowie. Raporty placówek polskich $w$ Niemczech, odpisy rezolucji, teksty oskarżenia, korespondencja, wycinki prasowe, instrukcje MSZ, k. 33-98.

AAN, Ambasada RP w Waszyngtonie, sygn. 2359, Wewnętrzna sytuacja polityczna w Polsce, nr 3907, 5 października 1925 r., Waszyngton, k. 23-24.

AAN, Biuro Naczelnej Rady Odbudowy Warszawy i Rady Głównej Społecznego Funduszu Odbudowy Kraju i Stolicy w Warszawie, sygn. 215, Budowa pomników Hibnera, Rutkowskiego, Kniewskiego na Cytadeli. Kosztorys, wniosek inwestycyjny.

AAN, KPZU, sygn. 165/I-2/t. 9, II Zjazd KPZU, k. 12-13, t. 9, k. 12-13.

AAN, Protokół IV Konferencji KPP, sygn. 158/II-4/t. 9, Przemówienie tow. Ignaca, k. 196.

AAN, Protokół IV Konferencji KPP, sygn. 158/II-4/t. 9, Rezolucja w sprawie świetlanej pamięci tow. Botwina, Hibnera, Kniewskiego i Rutkowskiego, k. 9.

AAN, Zbiór akt osobowych działaczy ruchu robotniczego 1918-1990, sygn. 297/II - 1682, Mirosław Zdziarski, k. 21-25.

AAN, Zbiór akt osobowych działaczy ruchu robotniczego 1918-1990, sygn. 689, Botwin Naftali, J. Ehrlich, Moje wspomnienia o towarzyszu Botwinie, mps, k. 27.

AAN, Zbiór akt osobowych działaczy ruchu robotniczego 1918-1990, sygn. 689, Botwin Naftali, J. Reiter, Krótkie wspomnienie o moim zetknięciu się z tow. Naftalim Botwinem (Ćwinek Tulu), Szczecin, 26 IV 1950, mps, k. 8-9.

AAN, Zbiór akt osobowych działaczy ruchu robotniczego 1918-1990, sygn. 689, Botwin Naftali, J. Reiter, Naftali Botwin ps. „Ćwinek”, „,Tulu”. Garść wspomnien, Warszawa, 30 IV 1960, mps, k. 29-35.

AAN, Zbiór akt osobowych działaczy ruchu robotniczego 1918-1990, sygn. 689, Botwin Naftali, O Naftalim Botwinie, Relacja Stanisława Radkiewicza nagrana w ZHP dnia 5 listopada 1963 r., k. 36-38.

AAN, Zbiór akt osobowych działaczy ruchu robotniczego 1918-1990, sygn. 689, Botwin Naftali, S. Ludwińska, W 60-tą rocznicę urodzin, Warszawa, 8 II 1965 r., mps, k. 43-45. AAN, Zbiór akt osobowych działaczy ruchu robotniczego 1918-1990, sygn. 689, Botwin Naftali, W. Atłas, Towarzysz Botwin, k. 13-24. 
AIPN, MBP, sygn. 1572/1615, Konfidenci i prowokatorzy Policji Państwowej do 1939 r. Członkowie KPP i KZMP w województwie warszawskim.

RGASPI, f. 495, Komintern, op. 252, d. 119, Akta personalne Stanisława Radkiewicza, k. 7, 25.

RGASPI, f. 496, op. 252, d. 501, Teczka osobowa Mirosława i Zinaidy Zdziarskich, Autobiografia Mirosława Zdziarskiego, 5 XI 1928, k. 137-138.

\section{Czasopisma}

Breza T., Niebo i ziemia. Fragment z II tomu powieści, „Dziennik Literacki” 1950, R. IV, nr 36, s. 1-2.

Człowieka-żal, prowokatora - nie, „Głos Olsztyński” 1950 (9-10 VIII), s. 3.

Dalszy przebieg śledztwa. Botwin grozi głodówka, „Gazeta Poranna” 1925 (1 VIII), nr 7496, s. 2.

Echa morderstwa, „Gazeta Lwowska” 1925 (1 VIII), nr 174, s. 2.

Echa politycznego mordu, „Gazeta Lwowska” 1925 (2 VIII), nr 175, s. 3.

Jaeger i towarzysze przed sądem, „Kurier Lwowski” 1925 (26 VII), nr 173, s. 1.

Kostanecki S., Mirosław Zdziarski (1892-1939), „Rocznik Mazowiecki” 1969, t. II, s. 309-339.

Mord polityczny, „Gazeta Lwowska” 1925 (30 VII), nr 172, s. 3.

Oburzające porównanie, „Kurier Lwowski” 1925, nr 185, s. 1.

Orzechowski I., Z okazji 23-rocznicy bohaterskiej śmierci tow. Botwina, ,Trybuna Robotnicza" 1948, z. 1350, s. 5.

Pańczyszyn placze się w zeznaniach, „Gazeta Poranna. Ilustrowany Dziennik Informacyjny Wschodnich Kresów” 1925, nr 7496, s. 1.

Po dokonanym przez sow-terrorystów morderstwie, „Kurier Lwowski” 1925 (31 VII), nr 177, s. 1.

Po krwawem morderstwie komunistycznym, „Kurier Lwowski” 1925 (1 VIII), nr 178, s. 1.

Po zbrodni, ,Słowo Polskie” 1925, nr 206, s. 1.

Prajs J., Relacja o śmierci prowokatora. Na podstawie opowiadań Bronistawy Wajnberg, „Życie Literackie” 1958, r. VIII, nr 49 (359), s. 1, 8.

Proces Botwina we Lwowie, ,Ilustrowana Republika” 1925, nr 10, s. 1.

Pyrig М., Взаємини Комуністичної Партї̈ Західної Украӥни та Комуністичної Партії Польщі у 1920-х рр., „Komunizm: system-ludzie-dokumentacja” 2014, s. 21-48.

Radziejow ski J., Ideologiczne i organizacyjne ksztaltowanie się ruchu komunistycznego na terenie Ukrainy Zachodniej w latach 1918-1923, „Z Pola Walki” 1971, nr 2, s. 27.

Sprawiedliwości stało się zadość, „Kurier Lwowski” 1925, nr 184, s. 1.

Terroryści komunistyczni mordują!, „Kurier Lwowski” 1925, nr 176, s. 1.

„Ulica Botwina” - w Bobigny. Kongres socjalistów francuskich o prześladowaniach w Polsce, „Kurier Poranny” 1925 (23 VIII), s. 18.

Wykrycie olbrzymiej, tajnej drukarni komunistycznej we Lwowie, „Kurier Lwowski” 1925 (8 VIII), nr 184, s. 1. 


\section{Książki, monografie}

Axer E., Z pamięci, Warszawa 2006.

Cimek H., Kieszczyński L., Komunistyczna Partia Polski 1918-1938, Warszawa 1984.

Czubiński A., Komunistyczna Partia Polski (1918-1938). Zarys historii, Warszawa 1985.

Dłuska M., Schoenbrenner J., Historia dla klasy IV, Warszawa 1953.

Hoesick F., Sprawa Józefa Muraszki: zabójstwo Bagińskiego i Wieczorkiewicza, Warszawa 1926.

Juryś R., Kulisy wielkiej prowokacji, Warszawa 1968.

Krzemień L., Związek Młodzieży Komunistycznej w Polsce. Pierwsze dziesięciolecie (1918-1928), Warszawa 1972.

Łabędzki Ł., Na granicy dwóch światów. Walery Bagiński 1893-1925. Biografia, Łódź 2010.

Ławnik J., Represje policyjne wobec ruchu robotniczego 1918-1939, Warszawa 1979.

Mazur G., Życie polityczne polskiego Lwowa 1918-1939, Kraków 2007.

Pepłoński A., Policja Państwowa w systemie organów bezpieczeństwa Drugiej Rzeczypospolitej, Szczytno 1991.

Pragier A., Czas przeszty dokonany, Londyn 1966.

Pyrig М., УКРАЇНСЬКИЙ ЛІВОРАДИКАЛЬНИЙ РУХ У ПОЛЬЩІ (1919-1929 рр.), praca doktorska, Uniwersytet Lwowski, [b.m.w.] 2016.

Radziejowski J., KPZU 1919-1929. Węzłowe problemy ideologiczne, Kraków 1976.

Urbanek M., Broniewski. Miłość, wódka, polityka, Warszawa 2011.

Wymiana więźniów politycznych między II Rzeczpospolita a Sowietami w okresie międzywojennym. Dokumenty i materiały, oprac. W. Materski, Warszawa 2000.

\section{Prace zbiorowe}

Historia Polski 1864-1945. Materiały do nauczania w klasie XI, red. Ż. Kormanowa, Warszawa 1952.

Kazetemowcy. Zbiór szkiców i biograficznych wspomnień, red. R. Toruńczyk, W. Góra, Warszawa 1963.

Komuniści w międzywojennej Warszawie, red. E. Kowalczyk, Warszawa 2014.

KPP: Uchwaty i rezolucje, red. J. Kowalski, F. Kalicka, Sz. Zachariasz, wstęp J. Kowalski, t. II, Warszawa 1955.

Stownik biograficzny działaczy polskiego ruchu robotniczego, red. F. Tych, t. I, Warszawa 1978.

Wywiad i kontrwywiad wojskowy II RP, t. 1, red. T. Dubicki, Łomianki 2010. 